\title{
A Theological Statement on the Coronavirus Pandemic
}

\section{Living the Faith Responsibly}

\author{
N. Barney Pityana, coB $^{1}$ \\ Honorary Professor, Department of Philosophy, Allan Gray Centre for \\ Leadership Ethics, Rhodes University, Grahamstad, South Africa; \\ Honorary Professor, Critical Studies in Higher Education Transformation, \\ Nelson Mandela University, Port Elizabeth, South Africa \\ bpityana@gmail.com
}

\begin{abstract}
This Statement is a response to the challenge that the church and Christian communities around the world face as a result of the spread of the coronavirus pandemic and the regulations that have been imposed in order to control the spread of infections. The paper starts off by explaining that pandemics may be a challenge and an opportunity to the faith. Special attention is paid to the coronavirus pandemic, its origins, the effect on public health systems around the world, and its impact on the socio-economic livelihoods; the role of medical health scientists and the breakdown and disruption of communities, the economic arrangements of states. It also raises questions about the possibility of a new world order that seeks a more equal, compassionate and humane world. On that basis, the paper raises some pertinent theological questions that arise for the church and for faith communities. It explores and examines theological questions that arise out of a world that is broken and suffering, beset by devastation and yet called to live the faith responsibly and truthfully. The questions that arise are preeminently about God and the meaning of the divine and how God manifests Good

1 Retired Principal and Vice Chancellor: University of South Africa; Professor emeritus of Law: University of South Africa; Visiting Honorary Professor: Department of Philosophy, Allan Gray Centre for Leadership Ethics, Rhodes University; Honorary Professor, Critical Studies in Higher Education Transformation, Nelson Mandela Metropolitan University; Member and Deputy President: Academy of Science of South Africa; Advisor/Consultant: Thabo Mbeki Foundation. The author wishes to acknowledge a partnership with the Rt. Revd. Luke Lungile Pato, Bishop of Namibia, in the development and shaping of this essay. As author, however, I take responsibility for the ideas reflected in this work.
\end{abstract}


during dark times. The paper raises some of the dilemmas that traditional faith practices are confronted by the pandemic especially in areas like worship, the sacraments and understanding the value of technology in the practice of the faith. Finally, the paper explores implications for the life of the church, especially in the moral life of the Christian community and the dilemmas posed by public ethics.

\section{Keywords}

coronavirus pandemic - covid-19 - South Africa - God - being church - human suffering

The Revd. Tiyo Soga (1829-1871) is a much acclaimed and celebrated man of letters, a pioneer missionary and hymn-writer who ministered at mission stations in the Eastern Frontier of the Cape Colony until he died in 1871. Trained in Glasgow and ordained a minister in the Presbyterian Church in 1856, he returned home in April 1857 aboard the steamship, Lady of the Lake. At the time of his return the Xhosa communities in his native eastern part of the Cape Colony were ravished on account of a millenarian movement associated with a young prophetess by the name of Nongqawuse, whereby cattle were slaughtered, crops destroyed, homes and livelihoods no more. This millenarian movement was as much a struggle to roll back colonial conquest by means other than the 100 years of wars. It was to be yet another tragic defeat. This was at a point where the Xhosa people were to surrender their patrimony, and their sovereignty, to the occupying colonial settlers. The voice of a teenage prophetess had been enough to rally the entire nation to the cause.

There was a famine across the land as a result, and by 1857 it was evident that the millenarian project had failed. The Xhosa people had experienced not just the loss of their hard-earned wealth, but the "last throw" of the dice in asserting their independence and sovereignty had also failed dismally. The mood in the nation must have been somber and shrouded in doom, gloom and despair, with any hope of new life destroyed. The resultant famine meant that hundreds of people died on account of their belief and their deep-seated determination to rid their land once and for all of the invading foreigners, with the assistance of the ancestors. The result was that miserably famished Xhosa people were scattered across the Eastern Frontier in search of food, hospital care, and a new life. Many of these desperate people landed at mission stations seeking help for life. 
The irony is that where both missionary endeavours and colonial conquest had failed, it was famine that reduced a once proud nation to submission.

Upon landing at Algoa Bay in 1857 with his newly-wedded Scottish wife, Janet Burnside, Soga penned the immortal words of a hymn that spoke directly to the hearts and prayers of the people, especially of the remnant of the Xhosa people, Lizalis'idinga lakho. ${ }^{2}$ Over the years, Soga's hymn has become something of an anthem. It is a psalmic poem of confidence in God, of the God of grace, and a prayer for renewal (or revival?) and restoration of the fortunes of the nation:

Fulfill, O Lord, your Promise (or Covenant)

Lord, God of Truth

May all nations and tribes

Receive your salvation

$\cdots$

And in the last verse, he prays

Revive us, Lord

That we may restore goodness.

Tiyo Soga's hymn is a testament of faith and hope in the midst of a devastating national catastrophe. For the hundred years between 1779 and 1878, Xhosa people fiercely resisted conquest and dispossession. At the same time foundations were being laid for the imposition of the Christian faith and colonial rule among native peoples by annexation. Soga was the great interpreter of the mood of the Xhosa people at this time, extracting meaning out of these circumstances of hopelessness, despair, fear, and gloom.

Such depth of faith in the midst of an overwhelming moral calamity is similarly captured, in our time, by Pope Francis in his second encyclical, Laudato Si (2015). ${ }^{3}$ Writing at a time of great outrage and anxiety about climate change and environmental devastation caused by years of human disregard for the fragility of nature, and in the eyes of some, a moral depravity that raised questions about the belief systems of modern humanity, the Pope opines that "[f]aith allows us

2 See my Tiyo Soga Lecture, Lizalis'idinga Lakho and the Legacy of Tiyo Soga, hosted by the University of Fort Hare, East London Campus, 7 December 2010.

3 His Holiness Pope Francis, Encyclical Letter Laudato Si' of the Holy Father Francis on Care for our Common Home, 24 May 2015, http://www.vatican.va/content/dam/francesco/pdf/encycli cals/documents/papa-francesco_20150524_enciclica-laudato-si_en.pdf. 
to interpret the meaning and the mysterious beauty of what is unfolding."4 The Pope reminds us that at times of great difficulty, that is exactly the time when our faith resources are being called to active service. He also says that faith provides us with tools and instruments for unravelling the truth and meaning by spiritual insight and intelligence. What is remarkable about this imagery is the capacity to "know" what is in the process of revelation (but not yet fully in flower!) and its quality of beauty. In other words, an appreciation of what is yet to be. Finally, faith provides one with the power to transcend the present material conditions, and to perceive the beauty that is shrouded in mystery and yet opening up like the petals of a flower at springtime. Hope then, lies in the assurance that out of a situation of crisis, there is hope for a new life and a new beginning. That is faith.

These two examples, one historical and localised, and the other contemporary and cosmic in scope, provide us with an instrument to read and understand the signs of our times. They speak to us about Faith and Hope not just when all is rosy but when times are hard. They are about exploration and meaning, seeking to interpret what lies beyond the obvious. In Kantian terms, it is a search for a transcendental logic.

The global crisis caused by the Covid-19 pandemic is such a time. It is a pandemic no different to many others that have beset humankind, and that visit in regular cycles. Each pandemic demands its unique understanding and responses. In some respects the millenarian tragedy of $1856 / 7$ in the Eastern Frontier of the Cape Colony, and the ongoing environmental or ecological disaster that entails global warming and climate change, are all due to human agency. Yes, it may have been with good intentions as was the case with Nongqawuse's prophecy that would have presaged freedom from the yoke of foreign repression, or the effects of industrialisation and modernity that destroy the environmental shield. The Paris Agreement (2015) is a universal accord that binds nations to restrict and limit gas emissions that result in the unfavourable climate change. ${ }^{5}$ The papal encyclical seeks to add a voice of faith, enjoining humankind to pull back from this global environmental disaster.

Worldwide, 2020 will be known in the annals of history as the year of the Global Covid-19 Pandemic. Records will show that in a short period of about three months since it first emerged in the city of Wuhan, China, in December 2019, some 5000 people world-wide had succumbed to the pandemic in various

4 Francis, Encyclical Letter Laudato Si', 57.

5 See United Nations Framework Convention on Climate Change, Global Climate Action Agenda (2018). 
parts of the world as far apart as Wuhan in China, to the Lombardy district of North Italy, across Europe, the Americas and Africa. The whole inhabited planet is currently engulfed in a multi-layered crisis by reason of the pandemic.

To understand the meaning of this pandemic, and to design appropriate human responses to it, is the subject of this essay. This essay not only seeks to understand in a scientific sense but also to explore lessons that can be learnt and how human community can most likely emerge resilient from the worst effects of this crisis. The thesis advanced here is a faith-ethic of responsibility.

\section{The Coronavirus Pandemic in Context}

Only a crisis - actual or perceived - produces real change. When that crisis occurs, the actions that are taken depend on the ideas that are lying around. ${ }^{6}$

In December 2019, a previously unknown strain of a severe and acute coronavirus was diagnosed in Wuhan City, China. Since then the virus has spread to over 188 countries, the worst affected of them, besides China, are the United States, Spain, Italy, the United Kingdom, among others. Infections have spread far and wide, almost at the speed of lightning. In the era of globalisation and free movement of goods and people, the spread and development of infections due to the virus is almost unstoppable. This is complicated for the moment by the knowledge that there is currently no known vaccine that can cure the infection, and no medical means of curbing the spread of the virus. To date around the world some 56.9 million cases have been identified, 1.36 million people have died from the virus; tests are being conducted and some 39.58 million people previously confirmed positive from the virus have recovered. ${ }^{7}$ Around the world, daily about $65^{\circ}, 433$ infections are recorded, and the current daily mortality rate is 11,274 people. ${ }^{8}$ As far as Africa is concerned South Africa remains the country most affected by the novel coronavirus. The official South African count is as follows: 757,144 positive cases identified, 701,534 recover-

6 Milton Friedman, Capitalism and Freedom (Chicago, IL; London: University of Chicago Press, 1982), xiv.

7 As at 19 November 2020. These numbers are constantly changing, with upsurges in infections in the United States of America and across Europe. The international figures from https:// www.worldometers.info/coronavirus/.

8 See Johns Hopkins University Coronavirus Resources Center, coviD-19 Dashboard, https:// coronavirus.jhu.edu/map.html (on 20 November 2020). 
ies, and 20,556 deaths. ${ }^{9}$ The World Health Organisation has declared this to be a global pandemic thus propelling the whole world into a disaster mode of unimaginable proportions. The virus at the centre of the storm of infection and disease is known as the novel coronavirus, or SARs-CoV-2, and the resulting pandemic, Covid-19.

Daily in South Africa, television and radio news bulletins provide tallies and updates on the spread and devastation caused by the virus, often in graphic detail, with graphs and maps illustrating prevalence rates, areas and districts of prevalence, as well as human stories of affected people, communities, and deaths. In South Africa, daily, cabinet ministers and other health officials appear before the nation to pronounce on the grim details of deaths and the devastation caused by the virus, keeping the nation informed about progress and setbacks. This comes with health advisories comprising information on ways in which the public might get protected from infection: wearing masks to cover mouth and nose; washing hands diligently and frequently; using sprays and hand sanitizers; maintaining social distance; and no hand-holding, hugs, or kisses. There are appeals for the populations to take their own health into their hands wherever possible. Education and information about the coronavirus are exhaustive. The good thing is that there is enough information out there for citizens to take care of their own health, but it is also sufficient to numb one's senses and justifiably cause fear and panic.

Due to the severity and magnitude of the spread of the Covid-19 global pandemic, by Notice dated 15 March 2020, the President of South Africa, Cyril Ramaphosa, declared a National State of Disaster in terms of the Disaster Management Act, 2002. This declaration was meant to give government extraordinary powers to manage and control the spread of the virus and to be able to adjust and redirect resources in order to best handle the looming disaster. A National Disaster Command Council (N DCC) was established, within which there was a Medical Advisory Committee made up of health experts, scientists, and specialists whose task was to advise the President and the Council. Regulations were then promulgated in order to establish the nature and scope of the responses to the infections recorded. On 23 March the President announced that there would be a nation-wide lockdown as from 26 March 2020, which was to be enforced by the deployment of South African Police to enforce the restrictions that had been promulgated, with the assistance, in the first instance, of some 2,820 SANDF troops, later increased to 73,18 o personnel. Not only did the

9 Department of Health, Republic of South Africa, Covid-rg Online Resource and News Portal, https://sacoronavirus.co.za/. 
Regulations impose a nation-wide lockdown on freedom of movement of all citizens except those undertaking essential services, a curfew curtailing movement during the night hours, limiting free movement only to those who seek medical assistance or to purchase essential food, closure of entrance points to the country and airline travel, international and domestic flights. Schools were also closed, transport limited, workers could not go to work, places of entertainment or worship, or sport, were shut, travel was severely restricted, and borders were closed. There was also a total ban on the sale of cigarettes and alcohol. These were, in any estimation, drastic measures imposed on the civilian population, especially during peacetime.

In a short four week-period, later extended by another two weeks, and thereafter repeatedly extended (lockdown level 3, with some loosened strictures, started 31 May 2020; the country is currently in lockdown level 1, which started on 21 September 2020, but many regulations remain in place), citizens were not only forced to stay at home under pain of penalties, but suddenly citizens found themselves under siege, with visible police and army activity, harassed, forced to explain movements, to produce permits - their freedom compromised! The intention of all these extraordinary measures was to restrict the spread of the infections ("flatten the curve," as the saying goes). At the same time measures were taken to enhance communication systems, educating people about this unprecedented public health hazard, and promote citizen participation in the control and management of the disease.

This entailed enjoining public cooperation and voluntary compliance, enforcement of the measures where necessary, advisories on appropriate and safe social conduct, namely, social distancing, frequent adherence to hygiene measures like washing of hands, and the avoidance of hand greetings. Sneezing and coughing onto the inside of a bent inside of the elbow, wearing a mask, regular changes of clothes, avoiding densely populated areas and crowded places, using hand sanitiser, and spraying and disinfecting surfaces continue to be communicated. While all this was taking place, government health services were engaged in preparing the public health systems, acquiring purpose-built field hospitals, employing additional health personnel, while increasing testing and facilities for quarantine and isolation of suspected cases in the expectation of an avalanche of cases admitted to hospitals.

For the purpose of this essay it is important to point out that churches and all places of worship were not exempt from these provisions. Buildings and places of worship had to be closed, no public acts of worship were permitted, and ministers were not exempt from limitations of movement such that parishioners in these strange circumstances were virtually without pastoral assistance in cases of need. Weddings and funerals were also similarly restricted. 
In the United States of America, a move by a church in California to challenge the regulations in so far as they prevented freedom of religion, so it was alleged, was dismissed by the Supreme Court of the United States by a margin of $5^{-4}$. The Court ruled that the restrictions were not in violation of the First Amendment to the Constitution in that the churches were being treated in a manner not dissimilar to comparable secular activities and that in any event the restrictions seek to achieve legitimate purposes. It was said that this case was the first ruling by the Court to balance the public health crisis against the Constitution's protection of religious freedom..${ }^{10}$ Needless to say, for many, such restrictions by secular authority present grave matters of conscience. For others they bring to bear fundamental theological problems about the manner of being church, and the capacity of the church to worship and to administer the sacraments. It must be stated, however, that in many instances church leaders have voluntarily collaborated with civic authorities for the greater good of society in times of danger. However, there are cases especially in the United States of America, where these have been reduced to political contestation. Above all, to some, it raises the spectre of the church vs. state confrontation.

The view that is taken in this essay, however, is one that strikes a balance between these contending views. It is our view that the church and religious societies will always remain essential features of a modern community living, through the coronavirus crisis and beyond. However, in order to deal with the crisis religious communities must also seek no special favours, instead they are obliged to place themselves in the hands of public services that address the national health crisis. They should rather seek to serve as the magnetic force of the social cohesion and to place themselves at the disposal of the community to serve the best interests of God in service to God's people. To that end the local parish has a role to play that is not incomparable to that which health and security practitioners might play.

Of course, all of this has been confusing to many. Rights and freedoms were taken away, the parliamentary and democratic processes were sidestepped, executive accountability was relaxed, and the measures meant to alleviate the worst effects of the government actions were bypassed, regularly amended and changed at will. South Africa became for all intents and purposes an executive state, as Parliament was all but invisible in public life. Some of the measures were taken with insufficient regard to the social context of the country where there were vast levels of inequality, where poverty was rife, and the resultant

10 Adam Liptak, "Supreme Court, in 5-4 Decision, Rejects Church's Challenge to Shutdown Order," New York Times, 15 June 2020, https://www.nytimes.com/2020/o5/3o/us/supreme -court-churches-coronavirus.html. 
unemployment caused levels of hunger and malnutrition that was never anticipated, let alone that the preventive measures proposed could not be practised in situations of population density, homelessness, and crowded spaces. Government responded by making funding available to alleviate suffering by the poor and the unemployed, food parcels were distributed, and assistance was provided to businesses that were strangled by the provisions of the lockdown.

The Covid-19 pandemic is a public health crisis of unimaginable proportions. It requires the State to have an adequate response to assist the public to maintain as much health as is possible. To do so, public health officials enjoy the advice and assistance of scientists, and an army of health practitioners were called into service to provide emergency health care. Hospitals, clinics, and other health care facilities had to be made available to respond to this crisis. This produces a double jeopardy: the ordinary health management activities of hospitals surely do not go away. Cancer patients need care, surgery is required to fix a myriad of ailments, maternity and neo-natal facilities are needed as normal. The second factor is that the nature of Covid-19 is that co-morbidities render those who suffer from ailments like high blood pressure, diabetes, heart and lung problems, HIV and Aids, and obesity most likely to be susceptible to infection and most likely to die. How those vulnerable people continue to receive appropriate health care even though the focus of health care provision has been diverted towards addressing the Covid-19 crisis, becomes an acute health management challenge.

The nearest that South Africa's public health service has ever had to contend with a catastrophe of this magnitude was the Spanish Flu pandemic in 19181919. At that time South Africa was very badly hit - some 300 ooo South Africans died within a period of about six months at the height of the outbreak. Around the world some 50 million people died of the pandemic. For South Africa it was indeed nothing short of "an irreparable calamity" resulting in the public health policy currently in use dating back to that time.

But Covid-19 is more than a public health crisis. It is as much a matter of health as it is also a socio-economic disaster. As a public health crisis it has focused the attention of the State on the one threat to public health, but while doing so it may have diverted attention from other public health crises in the country including HIV/Aids, neo-natal, maternal and child health facilities, non-communicable diseases, and various measures for preventive health necessary in a country like South Africa. It means that the entire economy has had to be repurposed for an indeterminate period. ${ }^{11}$ For South Africa that has come

11 The Standing Committee on Health, Academy of Science of South Africa (ASSAf), counsels as follows: 
at a time when the economy is on junk status and, set on a non-reversable path towards a recession, it is difficult to imagine how unwelcome all these moves could have been. Unemployment is at levels so high (at an official $30 \%$ ) that it is hard to say when last such a large number of South Africans were out of work. Predictably the Quarterly Labour Force Survey by StatsSA paints a grim picture of the employment outlook for the country. Poverty levels were, consequently, very high, inequality bothersome, housing just not meeting demand, and for many South Africans, hunger and starvation are a daily hazard.

In such circumstances and conditions, it is difficult to maintain the observance of the regulations to the stricture required to push back infections. In densely populated areas among the poorest South Africans, social distancing, washing of hands, sanitisers, and the wearing of masks, were all but a distant dream, made worse by the chronic unavailability of water and sanitation, and for many without an income, food insecurity, and homelessness. Isolation and quarantine are just impossible to achieve within the social challenges that a large number of South Africans in densely populated communities face as a daily struggle of life. Even measures taken to take the homeless off the streets and provide food for them were quickly defied by those it was meant to help. Government, correctly, sought to make provision to meet such socio-economic needs as were exposed by the lockdown regulations.

What is least talked about, though, is the impact of Covid-19 and the lockdown on the psychological health of people being confined to their homes,

"Until we have a vaccine or a cure, CoviD-19 might be amongst us for a while. Finite resources cannot be diverted solely to the pandemic. Careful priority setting, taking into consideration the costs and benefits of basic health interventions and services, are critical to the success and sustainability of public health gains of the past decades, while simultaneously addressing the CoviD-19 pandemic.

There is also an urgent need for transparent and explicit decision-making that takes into account the losses and gains of shifting resources and simultaneously fostering equity in the distribution of health expenditure and subsequent outcomes.

When developing guidance for the health system and weighing different options, policy makers must consider the potential effects of CoviD-19 on South Africa's complex disease burden. We need to ensure the continuity of health promotion, disease prevention and treatment services in order to avert excess death from the top four conditions and to prevent increases in their incidence during and after the CoviD-19 pandemic. Even if the resources at health facilities were not crowded out by focus on Covid-19, the economic impact of the pandemic, such as increased unemployment, has the potential to erode spending power of those who can no longer afford to pay their transport costs to the clinic" (issued on 3 July 2020), ASSAf Standing Committee on Health, "COviD-19 Statement: The Unanticipated Costs of covid-19 to South Africa's Quadruple Disease Burden," S Afr J Sci 116, no. 7/8 (2020); Art. \#stao321, 2 pages, https://doi.org/10.17159/sajs.2O2o/stao321. 
especially in places where the "homes" were rather rudimentary informal structures. The effect of gender violence, abuse of women and children, depression and mental health, and family violence were widely reported. Crime at all levels was noticeably at a minimum during the first phase of lockdown, especially given that alcohol was not available, but as soon as alcohol sales were allowed, there was then a spike in these violent levels of crime, as well as a steep rise in road fatalities and violence against women to such an extent that there were calls for a ban or further restriction on the sale of alcohol. Also reported were widespread instances of the abuse of civil rights by the security forces, in some cases resulting in the deaths of civilians at the hands of army personnel and police officers. The extent and the enforcement of the Regulations have been challenged in the courts (see note 10 below).

Not least, on the psychological effect on South Africans, has to be the bombardment by wall-to-wall carpeting of information, such that it could cause numbness, and confusion and uncertainty, and pain about what could be true or not true at a time when fake news and false information competes with the scientific data that is now readily available. It means at one level, from the President to a succession of cabinet ministers getting time on television and radio, fear-inducing, panic-driving statistics of deaths and new infections causing a state of resignation, fear, depression and uncertainty. Such familiarity induces both a sense that cabinet ministers and all the public officials are normal and ordinary, and what they say need not be taken seriously, and yet, on the other, respect and trust may result from exposing themselves as people who care.

What then have we learnt about the novel coronavirus (2019-nCov; SARs(oV-2)? First, that the pandemic is here to stay, and it is no longer just a remote or a passing phenomenon. In a profound statement recently, the Minister of Basic Education, Ms Angie Motshekga, MP, proffered that South Africans and indeed the world, will have to learn to live with the disease just as we live precariously with so many other diseases. Secondly, we have learnt that this is an enigma. Nobody really knows much about it. Dealing with it is a voyage of discovery. Not only is there no vaccine or cure at this stage, but also not much is known about its provenance, causes, as well as its physiological or pharmacological substance, although by now, we know that it comes about by infection through human contact. It is also known that its genesis is human contact with its traditional carriers, bats or pangolins. Because it is so widespread, opportunistic, and fast it can happen to anybody and it happens at random to everybody. Dr. Helena Gayle of the Chicago Community and Care Trust describes this as a contagion that is "fast and furious." It is a deadly pestilence that by all accounts is bound to be with us for the foreseeable future. There is no quick-fix here. 
For all those reasons, it is rightly said that the new coronavirus constitutes a "new normal" for society. We shall live by the new rules, learn and practice new rules of social intercourse, conduct human affairs differently than we had been used to, manage health risks and learn new expertise in medical and scientific research.

For us in South Africa and in similarly unequal societies around the world, Covid-19 has exposed the fault-lines in our social and economic system. For example, the virus is most likely to affect and infect the poorer and less fortunate sectors of society thereby aggravating prevailing social and economic inequalities where the power relations benefit the few. The result is that in South Africa race and gender inequalities will prevail. In other words, the social determinants of health should now become an intrinsic part of social and financial planning. In some measures that is because their social circumstances mean that they are less protected from opportunistic diseases and suffer in general from underlying, pre-existent co-morbidities. That means that infection is most likely to end in death.

It is estimated that such communities are likely to suffer infection some $2^{1 / 2}$ times more than other better-off communities that are well-resourced - vastly disproportionate to the actual population demographics. These communities are more vulnerable, more likely to be unemployed, and, as such, confined to places where they are most likely to be infected, and with less access to sports, recreation and leisure facilities. Social inequalities also mean that such communities are likely to be less amenable to observing the protocols - as in over-crowding - and are therefore most at risk to disease and infection. Social and economic inequality therefore exacerbates the conditions for the spread of the disease.

And yet, it should never be a Hobson's Choice, between the devil and the deep blue sea. By its nature democracy is about making choices. Being a Christian implies that one has made informed choices for life (Deut 30:19). It is often stated that society today is confronted with a choice between safe living and livelihoods. The implication is that government has to prioritise health care systems, reduce infections, provide medical and nursing care for the sick, and do whatever is possible to save lives. The suggestion is that to do so may entail, of necessity, accepting that the economic well-being of citizens and the economic health of society may well get compromised in the process. That is a non-choice. The truth is that human well-being requires both good health and a quality of life. It can never be either/or. In other words what is required is nothing less than fullness of life.

In a recent article reflecting on the impact of the novel coronavirus on society and imagining the world post coronavirus, Israeli historian Yuval Noah 
Harari expresses a concern that, presented with the choice as stated above, one was called to abandon one's humanity and rights, and surrender one's intellect and moral responsibility to those in authority who must be trusted to have one's best interests at all times. That's a tough call. He argues rather that

... to achieve such a level of compliance and co-operation, you need trust. People need to trust science, to trust public authorities, and to trust the media. Over the past few years, irresponsible politicians have deliberately undermined trust in science, in public authorities and in the media. Now these same irresponsible politicians might be tempted to take the high road to authoritarianism, arguing that you just cannot trust the public to do the right thing. ${ }^{2}$

His view is that this is a big deal to ask. The South African courts have also, during the lockdown, reiterated the principle that civil authorities should do no more by way of compromising the rights of citizens as is strictly required to achieve lawful ends. Failure to do so will cause any action taken under the Regulations, for example, to enforce the compliance with the Regulations, to fall foul of the Constitution. ${ }^{13}$

\section{$3 \quad$ Beyond Covid-19}

Will there ever be such a "beyond"? It is doubtful. We are constantly reminded that we are bound to have to live with Covid-19 as just one among many ail-

\footnotetext{
12 Yuval Noah Harari, "Yuval Noah Harari: The World after Coronavirus," Financial Times, 2o March 2020, https://www.ft.com/content/19d9o3o8-6858-11ea-a3c9-1fe6fedcca75.

13 Khosa \& Others $v$ Minister of Defence et al, Case No.: 21512/2020, delivered 20 May 2020 in the Gauteng Division of the High Court of South Africa (Gauteng High Court) on the rights of citizens during the lockdown. There have been various challenges to the Regulations promulgated in terms of the Disaster Management Act: DeBeer \& Others $v$ The Minister of COGTA (Case No.: 21542/202O) delivered on 2 June 2020 in the Gauteng High Court; Sakeliga NPC v The President of the Republic of South Africa (Case No.: 22352/2020) handed down on 3 June 2020 in the Gauteng High Court; Democratic Alliance v President of the Republic of South Africa (Case No.: 21424/2020) handed down on 19 June 2020 in the Gauteng High Court; Duwayne Esau and Others v Minister of Cooperative Governance and Traditional Affairs (Case No.: 5807/2020) on the constitutionality of the National Command Council in the Cape High Court; Fair-Trade Independent Tobacco Association (FITA) $v$ President of the Republic of South Africa (Case No.: 21688/2020, dated 26 June 2020), on the constitutionality of the ban on tobacco sales under Alert Level 3 in the Gauteng High Court.
} 
ments that beset the human condition for the foreseeable future. We must come to terms with taking precautions against infections, manage infections efficiently, and protect life. In due course a vaccine will be found, and prospects of recovery will be a lot stronger and predictable than they are now. But for now, humanity must take precautions, live with social distancing and with all the advices that have been given to contain infections.

But more than that, it is now realised that the economic and social and economic system that had become established hitherto must also change for the better. It is now recognised that any economic and social policy that replaces the present system post Covid-19 must take account of this reality and be designed to close the gap of the prevailing social and economic inequality by promoting policies that create jobs, paying attention to housing, and water provision, as well as improving education, health care and social welfare, in short, towards a more caring, more just, and a more equal society. ${ }^{14}$ This we know that quality health care, among others, is rendered difficult in conditions of inequality and abject poverty for some.

Invariably, new ideas are now presenting themselves in the search for lasting solutions. The crises of our times require new solutions and these solutions are most likely to come from economists and social scientists. The crises have produced new thinking and new ideas. It is those ideas that are to place society on a new pathway towards a shared prosperity. In a penetratingly candid essay, "The Neo-Liberal Era Is Ending - What Comes Next?," Rutger Bregman takes a very positive and optimistic outlook:

The ideology that was dominant these last 40 years is dying. What will replace it? Nobody knows for sure. ... This pandemic could send us down

14 I believe that I shared the sentiments of most South Africans when I said the following at the Launch of the 7os Group on 10 April 2019 in Johannesburg: "Finally, we must pay attention to the moral character of this nation. That means that if this nation has any values to sustain itself, it needs to become a more caring and humane society that Nelson Mandela so famously epitomised. We can become a nation that cares for the elderly, that guarantees safety to our children, that they are nurtured and guaranteed a healthy future; that the poor are valued and will be given opportunities to discover their humanity and their value; and that there is nothing to be proud of about poverty and its dehumanising impact. Poverty and inequality must be defeated for good. We can live in this country without fear of violence, death, and demeaning racism. We must dream of a South Africa where women and children are not subjected to violence. We are free to dream of a South Africa where innovation, knowledge, and intellect are rewarded and valued; and creativity and the arts become an embodiment of our human capacity for good and for value. We need to give confidence back to the people of this country. What has been lost must be recovered." 
a path of new values. If there was one dogma that defined neoliberalism, it's that most people are selfish. And it's from that cynical view of human nature that all the rest followed - the privatisation, the growing inequality, and the erosion of the public sphere. Now a space has opened up for a different, more realistic view of human nature: that humankind has evolved to cooperate. It's from that conviction that all the rest can follow - a government based on trust, a tax system rooted in solidarity, and the sustainable investments needed to secure our future. ${ }^{15}$

For his part, the world-renowned French political economist, Thomas Piketty, believes that pandemics are an opportune game-changer in the world economy. In other words, the shock system will provide a self-correction to the system. He argues that inequality was unsustainable, and it was prone to cause eruptions and convulsions. He gives examples of previous pandemics and how they resulted in a "compression of inequality over the next half century." The solution for him is more and not less social welfare and taxation of the rich in order to pay for the challenges of reconstruction. ${ }^{16}$

Does this sound like the promise of a brave new world? We shall see.

\section{A Problem Statement:}

In an opinion piece in Time, New Testament theologian and professor at the University of St. Andrews in Scotland and former Bishop of Durham, N.T. Wright states that "Christianity offers no answers about the Coronavirus. It is not supposed to." Bishop Wright goes on to say that

[i]t is no part of the Christian vocation to be able to explain what's happening and why. In fact, it is part of the Christian vocation not to be able

15 Rutger Bregman, “The Neo-Liberal Era Is Ending - What Comes Next?", The Correspondent, 14 May 2020, https://thecorrespondent.com/466/the-neoliberal-era-is-ending-what -comes-next/61655148676-aooee89a. Read also Rob Wijnberg's article, "Why Climate Change is a Pandemic in Slow Motion (and What That can Teach Us)," The Correspondent, 7 May 2020, https://thecorrespondent.com/449/why-climate-change-is-a-pandemic -in-slow-motion-and-what-that-can-teach-us/10477915635-ffbbdegb.

16 Laura Spinney, "Interview: Will Coronavirus Lead to Fairer Societies? Thomas Piketty Explores the Prospect," The Guardian, 12 May 2020, https://www.theguardian.com/world/ 2020/may/12/will-coronavirus-lead-to-fairer-societies-thomas-piketty-explores-the-pros pect. 
to explain - and to lament instead. ... And out of that there can emerge new possibilities, new acts of kindness, new scientific understanding, new hope. New wisdom for our leaders? Now, there's a thought. ${ }^{17}$

In stating the challenge in the manner that he does, Wright surely challenges some of Christian theology's traditional questions about theodicy, Christian explanation, the authority of the Bible, etc. In other words, he points Christian curiosity and philosophy to precisely where it will not find answers. To put it differently, he offers no solution to the Christian faith dilemma but re-states the problem. In a sense he himself introduces a measure of deus ex machina to the problem much like what he is critical of. How does "lament" produce "new possibilities"?

Wright is challenged by an American theologian Owen Strachan of the Trinity Evangelical School of Divinity. Strachan challenges Wright's notion that there can be no hope and no explanation about God's activity in the world. For him, this notion goes against all the evidence of Christian life that God is omniscient, and that Christians are called to a life of hope. He ends his rejoinder to Wright in the following words:

... we come away from his article neither gripped by the force of resurrection hope nor struck by the beauty of a true and defensible gospel of grace. Instead, we are left pondering that God laments evil and suffering, yet does so without fullness of knowledge or power. ${ }^{18}$

True to character, in his positivist layperson's theological language the Chief Justice of the Republic of South Africa, Mogoeng Mogoeng, in a recent engagement with the Jerusalem Post has proffered that the pandemic has caused even people of faith to doubt: "suddenly the faith that they used to have in the Almighty God is not there anymore. People are fear-stricken."19 Clearly in his

17 N.T. Wright, "Christianity Offers no Answers about the Coronavirus. It's not Supposed to," Time, Ideas - Covid-19, 29 March 2020, https://time.com/5808495/coronavirus-christia nity/. There is a new book by N.T. Wright, God and the Pandemic: A Christian Reflection on the Coronavirus and its Aftermath (London: SPCK, 202O). I have not read the book yet but one supposes that it takes a line similar to the one that is in the above opinion piece.

18 Owen Strachan, "NT Wright Is Wrong: Hope in a Time of Pandemic," Reformanda, 1 April 2020, https://www.reformandamin.org/articles1/2020/4/1/nt-wright-is-wrong-chri stianity-offers-answers-and-hope-amidst-the-coronavirus-pandemic.

19 The discussion between the Chief Rabbi of South Africa, Warren S. Goldstein, and Chief Justice Mogoeng Mogoeng was moderated and hosted by The Jerusalem Post editor-inchief, Yaakov Katz, "Two Chiefs, One Mission: Confronting Apartheid of the Heart," The 
Christian lexicon faith generates a fearlessness even in the face of danger. In any event, fear is not a condition of being without faith. Fear may well be a recognition of the presence of God.

It is difficult to understand where Mogoeng gathers that kind of courage and boldness from Scripture that denies fear in the face of danger. But judging by the utterances of many evangelical ministers of the church in the United States of Ameerica, many of whom died of the coronavirus, they judged that their faith had to be tested by a reckless disregard for ordinary care. In other words, they were bold enough to tempt God. The Mogoeng proposition strikes me as reminiscent of the Great Temptation: "if you are the Son of God, then prove it ..." (Matt 4:1-11 and Luke 4:1-13). This then is the problem statement: is there a Christian way of being human and an ordinary person of faith in the face of a dreadful and deadly pestilence? N.T. Wright proposes what he believes is a Christian way of virtually waiting on God. Strachan says that the fundamental tenets of the faith persist and will deliver salvation.

In this essay, we propose to proceed by way of restating some tenets of the faith and testing them against the challenge society faces as outlined above. Yes, we shall take Wright's counsel against too easy notions that simply imply that where there are gaps in our knowledge and understanding, the answer simply lies in placing God in the gap as if that becomes the solution. Granted, the approach taken is both rational and post-modernist, but it is consistent with the crisis posed by the pandemic as postulated above. It will become apparent, thus, that in this essay, we take neither of the avenues suggested by our two eminent theologians because we take the view that both of them lead us to a dead-end. Instead we proceed by way of asserting God's being in human life that is as positive as the social scientists, referred to above, encourage us to envision. In other words, while we will not be drawn into the minutiae of the debate save for the fact that they point to the theological problem that an understanding of faith poses in times of crisis as in this pandemic, what it will do for us is to elevate the concept of God that is the subject of our study. The challenge we face today is straightforward: what does it mean to be a person of faith today, not so much about whether belief in God is rendered meaningless by the suffering caused by the pandemic, but rather how does one become fully human in the face of the suffering and beyond? So much is bound to change. Therefore, can we identify our faith practice any longer with what we have come to know to be what our faith teaches?

Jerusalem Post, 23 June 2020, https://www.jpost.com/diaspora/two-chiefs-one-mission-co nfronting-apartheid-of-the-heart-watch-632388. 
Christian theology works with tools in history, philosophy, culture, and language studies, as well as psychology to express this idea of the human, especially in its relationship with and understanding of God, as well as in its resultant moral life. Theology works with both heart and mind, feelings and intellect. To do so, Christianity is aware of the centrality of the relationship with God in the disposition of humans to do good and to create healthy and fulfilling relations, and especially the place of Jesus Christ in one's life. An understanding of Jesus, known as Christology, distils the totality of faith in terms of the origins and destiny of the human (eschatology), as well as a tradition of thought and practice that is continuous with the mind of the earthly Jesus and the faith in the glorious and Risen Christ of the Trinity, and in the life of the historic church. Christian theology, it has been said, is first and foremost, about the human and the totality of human relationships. Contrary to what some might perceive, theology is not just preoccupied with death and obsessed with heaven and with the ultimate destiny of the soul. It is in seeking to be fully human that one seeks to understand what God wills for one's life. Theological inquiry is devoted to the totality of life and all that influences and shapes that life, and all relationships or community that give meaning to that life (or rob meaning from that life).

For that reason, Christian theology is about the imagination. To bring the holy mysteries within the human understanding, Christian theology utilises a set of conceptual tools. It is by the power of the imagination that so much of Christian life makes any sense at all. To do so, it is through myth and symbols, story and meaning, worship and human expression in music, dance and movement, in poetry and in art, feeling and ecstasy, that the story of faith can be truly told, faithfully observed, and clearly understood to the extent that human nature with all its limitations can allow. So central is theology in the intellectual shape of the university that $\mathrm{H}$. Richard Niebuhr, for example, saw theology as a servant among disciplines of the university: "As fellow servant of truth in this sense theology takes its place in the university alongside other inquiries, never separated from them, never dependent upon them, never isolating itself with them from the totality of the common life which is the universe." ${ }^{20}$ Like theology therefore, Christian faith cannot simply be located at the margins of life but must actually constitute the very epicentre of one's being, becoming the

20 H. Richard Niebuhr, Radical Monotheism and Western Culture: With Supplementary Essays, foreword James M. Gustafson, Library of Theological Ethics (Louisville, KY: Westminster John Knox, 1993), 99. 
deep in a pond of knowledge disturbed by a pebble causing outward ripples to the outer world.

Elna Mouton of Stellenbosch University describes this phenomenon in apt terms as "the ability of the human imagination to re-describe reality, to re-name experiences, to re-tell their stories from new angles. This refers to the human capacity to speak metaphorically - to see new possibilities and to make new connections between known images and (past and present) experiences."21 This is what makes theology so exciting because it does not have any definitive answers for all time. It is constantly evolving as new knowledge or circumstances emerge. The imagination stretches the human consciousness beyond its physical limitations.

Theological knowledge, as Dietrich Bonhoeffer says, is provisional. It is the penultimate. Theology helps one not to be confined to the obvious, natural and material, but to explore the metaphysical world beyond with as much confidence as living in the material world. Indeed, the world that we live in and we purport to know is a metaphor. Theology exists to test all the capacities of the believer to explore meaning in search of the (elusive) truth. In this search for knowledge and meaning, says Pope Francis in his encyclical Laudato Si', we can think of "the whole as open to God's transcendence, within which it develops. Faith allows us to interpret the meaning and the mysterious beauty of what is unfolding." ${ }^{22}$ I take that to mean, as Anglican theology teaches, that faith and reason are inescapable Siamese twins. Reason helps to unlock the mysteries of creation, faith grants one tools to believe that it is possible to unravel truth out of nothing (ex nihilo), and by so doing unlock the mysterious beauty that lies hidden in matter.

To be a Christian is an acknowledgement of God as "presence" in one's life and in the world, or as one's response to the moment of encounter with a "living God." It is a life of confession of Christ in word and deed to be the Saviour of the world, salvator mundi. It is making account of the faith that is in one, and to be in continuous communicative relationship with the tradition of faith that has its source and beginning in Jesus Christ. A Christian is called to a dynamic relationship with that tradition, as understood and applied in the present for the reason that such a tradition is the fulfilment of the covenant between God and God's people.

21 E. Mouton, Christian Theology in the University: On the Threshold or in the Margin?, Kamper Oraties 30 (Kampen:Theologische Universiteit van de Protestantse Kerk in Nederland, 2005), 8.

22 Francis, Encyclical Letter Laudato Si', 57. 
The totality of the Christian tradition that one confesses is enduring exactly because of, as Mouton puts it, "their potentially persuasive power to affirm, to nourish and sustain life - to facilitate new possibilities, to encourage and to console, to invite, move and challenge their receivers to imagine and to reimagine - that makes them authoritative!".23

Contrary to what some may believe, the Christian faith is not a transactional religion or about bargaining with God over what would benefit one most by believing. In reality, Christians believe and practise their faith simply because oftentimes it makes sense to do so, or because it is to acknowledge the Godfactor as a complex measure of the human and the world that surrounds us. It is an acknowledgement of God in one's life and in the world. It is rather a compelling reflection and outworking of a life in the midst of a messy world. It makes God "visible" to the inhabited world. So understood, then, evangelism becomes an offer and an invitation to share the life of Christ, with Christ, and in Christ (to use Pauline phraseology). Mission is the location of God's people in the midst of a people in suffering and a people in the struggle for life and for liberation, who sat down and wept when they remembered Jerusalem. Mission is a bridge from the condition of fear, despondency to one of hope and confidence and to have a vision of God (Ps 137).

In my view none of this makes God secondary or supplementary. It remains true that Christian belief is less about God than it is about human understandings about God (for me this falls short of the atheistic accusation that faith is a mere projection of one's insecurities onto an other-being!). Theology for me begins with the human. The point here is that a truly faithful life is itself recognition of the joys and gifts of our humanity, and that such was given by God and belongs to God. To be human is to be derived in God and of God. In other words, as a piece of God, for a divine purpose. Being human is quintessentially a gift of God. If that is so, then it means that a belief in God and of God's Son Jesus Christ is to be alive to the Other, to their significance in making one fully human, the energy derived from such relationships, and the moral effect of living together in a community of sharing and loving, as in the Shema Yisrael (Deut 6:4-5), and extended by Jesus in Matthew and Luke (Luke 10:27, Matt 22:37). In the divine economy the dance between love, justice and righteousness is palpable, as is the romance in Ps 85:10: "Steadfast love and faithfulness will meet; righteousness and peace will kiss each other."

This idea of the Other is not only about the cognition, recognition, or even an acknowledgement of God. It is also about the knowledge that the Other is 
one's neighbour, who has needs and wants. It is a recognition of community as an essential lever of human existence. An appreciation of the Other becomes the essence of a moral society. This humanity, though, is one that is shaped by that relationship of the eternal covenant with God, that seeks and responds to the love of God, confident in the knowledge of and with humility that God is glorified in the being of the human. In fact, Christian doctrine teaches about God who became human in the doctrine of the Incarnation.

How then does this inform an approach to Covid-19? For being a Christian caught in the warp and weft of an unfathomable crisis of this magnitude, is to turn to God, yes, for answers, but also, that is what being human is about. To turn to God is both about confession and penitence, as it is in supplication. It is by the power of God that the faithful both understand and seek wisdom to find answers (Ps 53). God becomes present in the crisis situation. Christian theology for its part seeks to make sense of, and derive meaning from, the pandemic. We do not always know the sources of all things. If we did, then there would be no need to be curious about our physical environment. It helps one to understand that not everything that we experience today is known or knowable. It is in always being open to new knowledge and understandings that we become human. It is in the surprises of life that the knowledge of God gives substance and meaning. Learning and discovery are a continuous activity. While it may point to human limitations and require a more mature and reasoned understanding of God, nonetheless it encourages human responsibility.

And yet, Christian theology teaches that human living is never an act in futility but rather one infused with purpose. That purpose is to fulfil God's intentions in creation because, as Paul puts it, "God is faithful, and he will not let you be tested beyond your strength, but with the testing he will also provide the way out so that you will be able to endure it" (1Cor 10:13). To be a Christian is to abide in the confidence of God.

Finally, out of the cauldron that the new coronavirus pandemic presents, Christians must yet find it possible to contend with their reality of life and death, seek and find meaning for their lives, comfort, grieve and celebrate the fulness of life (or the precariousness thereof), ponder on the mystery that abides, and thank God for science, human care, and human solidarity. The search for meaning never reaches finality, nor is it confined to certain episodes of human experience. Meaning and explanation form the substance of being human. 
Acts 2:44-47 is perhaps the proof-text on the making of the Christian church from primitive times. The church exists because men and women have responded to the Christ event, bound together to a common and shared living, praying together encouraging each other, breaking bread together, and praising God continuously. The consequence of that is that the world takes notice, and more are added to their number as they are moved by the spirit of Christ. In other words, the Church is both apostolic and evangelical. It is called out to serve and by its life and witness it is a symbol and an agent of God's invitation to others to become part of the community of salvation. In a strange way, by doing so, the church is both in the world and mindful of it, but it also transcends that world and calls out for a transcendent living. To be church is to choose a way of life. This ambiguous relationship with the world is often tested severely - and so it should be. It is tested because it is never quite understood. It is also tested because it has provoked cynicism and even hostility.

The Anglican-Roman Catholic International Commission (ARCIC) over some forty years has been defining the essence of Anglican theology, especially in its relationship with the Roman Catholic Church, or as a means of promoting and advancing dialogue between the two churches. It is my conviction that in the process some amazing output of Anglican theology has come out of this process. At the heart of that theology about the church has been the idea of the Church as communion (or koinonia). Church is a community of those who are called, and who exist to serve God and the world as intercessors of communion between God and humankind. To that extent it is also a community of reconciliation. The idea of community is trinitarian because it draws from the dynamic communion between the three persons that form the God of the Revelation who inform each other into union with each other. The Report puts it this way:

The Church as koinonia requires visible expression because it is intended to be the "sacrament" of God's saving work. A sacrament is both sign and instrument. The koinonia is a sign that God's purpose in Christ is being realized in the world by grace. It is also an instrument for the accomplishment of this purpose, inasmuch as it proclaims the truth of the Gospel and witnesses to it by its life, thus entering more deeply into the mystery of the Kingdom. ${ }^{24}$

24 Anglican-Roman Catholic International Commission, Arcic I. The Final Report, 4 (\#7), https://www.anglicancommunion.org/media/105260/final_report_arcic_1.pdf. 
It is this theology of the Church that has been severely tested during the coronavirus lockdowns. It has meant that (1) the church must entrust secular authorities with the decisions as to how best to be church at difficult times in national life; (2) the church has to rethink the idea of koinonia and talk the strange language of a virtual church in the modern technological age; (3) the tasks of the church as community made visible by prayer and worship together, sacraments as well as mission and evangelism, must now be expressed differently; and (4) finally, at a time of the most acute need, the church may be absent from the lives of people to share with them the love of Christ in pastoral care and counselling.

The truth, though, is that we have already experienced that modern technology, while it may be convenient for some, it is a divider for others. The poor and maybe the elderly do not have access to and the privilege of technology. Secondly, technology by its nature is impersonal. It distances one from a human being who is impacted by another through personality - personality that is direct and unmediated. And yet technology is ubiquitous, and increasingly available and affordable as a means of communication. It becomes unavoidable therefore that technology could be one among many of God's gifts to offer praise and thanksgiving, and to reduce the divide between people and distance.

Let us face it, technology has redefined the idea of community on which the church is founded and shaped. We therefore conclude that technology should function best as an emergency, alternative or additional tool available to the church in times of hardship just like what the church had to do during persecutions, or in wartime. It ought not to be the means to detract from community at the human level. That means that technology cannot be the dominant means of being church. Technology must be part of the armoury available to the church to become an effective instrument for the witness of the church in the world.

Worship and the sacraments have also been affected by the new ways of being that have been imposed by having to live with the conditions of the coronavirus. Being Church is about the visible expression of unity and community, as well as the reconciling presence within and without that community. Worship is that which seals Christian life into togetherness. Technology has been an excellent means of bridging the distance between people, and thus brings about the collapse of location or place and event. However, worship is also about togetherness, sharing, holding hands, gestures and facial expressions, voice and laughter, or smiles. ${ }^{25}$ In other words, all the senses are fully engaged in the act of worship.

25 I am indebted to Revd Mark Spyker of St. Martin-in-the-Veld, Rosebank, Johannesburg (taken from his Facebook entry) for this apt description of worship from William Temple: 
The sacraments perhaps hold the most challenge in this new dispensation. How does the idea of a sacrament as an outward and visible sign of an inward and invisible grace, work? By definition, the elements of a sacrament are tangible, material things that get transformed (in the case of the theology of the Eucharist, transubstantiated) into the means of grace. The sign is visible and tangible or material. It is transmitted by transference, e.g., the laying on of hands, or, in Paul's words with gestures like "the right hand of fellowship" (Gal 2:9), the water of baptism, and the breaking of the bread and the sharing of the cup. It is through the combination of prayer and materiality that sacraments become efficacious, we believe. I doubt that sacrament functions by virtual means. It must be by the actual touching and praying. It does not make sense to me to have what is called "a virtual sacrament." It is not possible.

I put these matters as starkly as I can because I am uncomfortable with tooeasy solutions to difficult theological problems, or to take short-cuts where the harder theological grind is called for, even if it means that we need to rethink our theological propositions. Should we not take courage and push the boundaries of possibility? To put it differently, are we on the way to becoming a nonsacramental church? Are we on course to spiritualise the Incarnation, the God who became human and dwelt among us as in a tabernacle? Of course, it is assumed that social intercourse in various kinds will be resumed in due course. However, worship will have to be different because the scare of the virus will still be with us: physical and social distancing, worship without music, or dance in isolation! Everything is compromised. But that is only a passing phase.

Elna Mouton draws attention to the fact that in a postmodern age, the nature of authority has become thinner and most likely under challenge. ${ }^{26}$ Again, and again, people of faith express themselves in more assertive language and actions, at times individualistic rather than as community or collective, and in an information age, they have a variety of sources of knowledge and authority and they have high expectations. Ministry, therefore, is undergoing change. Knowledge is contested and truth relativised. The authority of the priest can no longer be taken for granted. At times truth must be negotiated, power is dispersed. In such an environment, leadership has to be both flexible, and open to learn and be receptive to new ideas. And yet, leadership has to be the source of tradition and authority that must not be surrendered to every whim and

"Worship is a submission of all our nature to God. It is the quickening of conscience by His Holiness, the nourishment of mind with His Truth; the purifying of imagination by His beauty; the opening of the heart to His Love; the surrender of will to His Purpose and all this gathered up in adoration."

26 Mouton, Christian Theology in the University. 
fancy. There is also a sense that in the modern age people are looking for certainties and for authority figures, but this quest for illumination and guidance must never be abused or taken for granted. The coronavirus has knocked the stuffing out of people. The minister and priest occupy an uncomfortable dialectical relationship with that system of mutual support that leadership requires. Their sense of confidence, living with fear and uncertainty, learning to love and to trust genuinely, are all in need of restoration. All this to suggest that ministry post-coronavirus must take on new meanings. It means giving effect to the teaching on both servant and shepherd, as well as the practice of empathetic leadership. At the same time, in a situation of utter brokenness there is need for a true care of God's people, working together to bind the broken-hearted (Luke 4:18).

Pandemics are regularly succeeded by a spiritual revival. Without doubt the coronavirus and lockdown are bound to induce a pining and a longing for God out of the isolation under conditions of fear and wonder. There will be a search for the spiritual centre of human life and a desire for reassurance as in Psalms 42:2-3 where the soul laments:

My soul thirsts for God, for the living God.

When shall I come and behold the face of God?

My tears have been my food day and night,

while people say to me continually, "Where is your God?"

Artur Weiser in his commentary on Psalms suggests that this longing for God is equally the power that sustains one through suffering and difficulty to bring comfort and hope. ${ }^{27}$ This longing for God is less about what one will get out of God, says Weiser, but rather about the being, in the nature, of God. Weiser concludes his commentary on Ps 43 with words that should reverberate through the mind of the church at this time:

No religion will ever be able to dispense with the cultus as the place from which man [sic] continually derives new strength for his struggle for existence through his communion with God and fellowship with the faithful. ${ }^{28}$

\footnotetext{
27 Artur Weiser, The Psalms: A Commentary, trans. Herbert Hartwell, The Old Testament Library (London: SCM Press, 1962), $35^{2}$.

28 Weiser, The Psalms, 352 (my emphasis).
} 
Contrary to what many in the church fear at this time, my conviction is that what we shall experience as church and nation as a result of the devastation of Covid-19, is a deep spirituality and a call for a servant church in the lives of many. That is not too difficult to understand given that death has been stalking every home, often in isolation and without the care and support of family, neighbours or friends; that the extraordinary circumstances of Covid-19 have been such that mourning at the time of the events of sickness and death has been restricted. Many will have lost their loved ones; many homes will have orphans and elderly in need of care. The mourning, of course, will also be about for those things in life that people would have lost, e.g., jobs, businesses that have collapsed, divorce and loss of friends. The social reconstruction of society will demand all the resources available to this nation. The church must be equal to the task.

Post-covid-19, therefore, people will be grasping for an anchor of spiritual sustenance - searching for meaning in the midst of futility and uncertainty, searching for God, reaching out for a firm foothold where the earth is moving, searching to discover and to understand who God is in their lives. The sheer scale of the human suffering, brokenness, hurt, pain, and suffering are bound to draw men and women of faith into searching and seeking for meaning in the midst of the futility that envelopes them. The full horror of the human degradation will never be fully comprehended. It is at times like these that people will be drawn to the substance of their faith.

At times like these the church has to be present to become the shield and anchor; and to call men and women to a life of prayer, worship, sacraments, and a symbol or witness of God's love for the world. The church must be there to call the faithful to prayer and to ring with confidence in the loving God. For that reason, life beyond Covid-19 must be planned carefully and people's emotional location must be taken care of. It seems to me that sacraments like confession, anointing the sick, counselling as well as the Eucharist, are bound to assume a greater measure in ministry. This is to suggest that the symbolic value of the church, praise and worship, and the stature of priesthood must remain. Priestly ministry will be in greater demand in the years ahead. It may well be the case that ministers and priests of the church will need a new engaged training and preparation for the times ahead. Above all the church must stand tall as a symbol of resilience and of God's presence, and as the heart of the community yearning for love and care. It is easy to anticipate that there will be an outpouring of the love of God in thanksgiving and in prayer for salvation. That will demand extraordinary resources for ministry. Ordained men and women should be trained to serve, to teach, to care and to serve as a moral guide to a perplexed community. 
The Arusha Call to Discipleship is pertinent here. ${ }^{29}$ It is the Final Statement of the World Council of Churches' Conference on World Mission and Evangelism, "Moving in the Spirit: Called to Transforming Discipleship," held in Tanzania 8-13 March 2018. The statement makes a compelling case that Christians are called to faithful discipleship, learners at the feet of Christ, discoverers of the truth about Christ and the World. It says forcefully that "discipleship is both a gift and a call to be active collaborators with God for the transforming of the world (1 Thessalonians 3:2)." It goes on to say that

This journey of discipleship leads us to share and live out God's love in Jesus Christ by seeking justice and peace in ways that are different from the world (John 14:27). Thus, we are responding to Jesus' call to follow him from the margins of the world.

The church as a transforming and reconciling community seeks in its life to manifest the salvation of the world and the glorification of God the Father in its life and work. Mindful that Christians and the world in society have failed to live up to the commandments of the loving God, the church is complicit in society's failure to abide by the moral order to which the church bears witness. As a moral exemplar of Christ in the world the church serves also as a reconciling agent between God and society, but more than that, rooted in the world the church also seeks to draw all the faithful to the Transcendent Love that is God.

That moral order is one that pours out the life of Christ as victim and sacrifice for justice and peace in the world. To that extent it is a sacramental outpouring of grace under God. That is the responsibility we seek to uphold as the church. Recognising that Covid-19 has exacerbated the brokenness of the world, causes men and women to live together in distance and in relationships of mutual suspicion, the church must recognise that all is not well - and that unwellness afflicts the church first just as much as it has devastated the world. In that sense Covid-19 could be an opportunity and an occasion for reconciliation and a restoration of the lost relationships. It is worthwhile to ponder as to the kind of church that will form itself post Covid-19?

29 World Council of Churches, The Arusha Call to Discipleship, 13 March 2018, https://www .oikoumene.org/resources/documents/the-arusha-call-to-discipleship. 
What then would the church be in such a social setting? Perhaps the image of a bridge may be apposite. A bridge provides the means of transference from one state of being to the other, in safety. But for the bridge to serve its purpose it must be firmly rooted in the confidence of that which upholds it and holds it in place. Without the firmness of faith, a bridge will not serve its purpose. The bridge is also about pointing beyond itself and providing a service that is not just itself. For that reason, the bridge serves to bring the faithful closer to God. As a moral substance, being human is about taking responsibility and understanding the operations of human agency. As agents of God, humanity is continuously a part of the making and unmaking of Creation. If that is so then choices are made in such a way as to fulfil the acts of God. In reality this human agency can be observed in the work of scientists and researchers seeking, by the skill and expertise of science, to find a vaccine that will bring health to those who might otherwise be dying as a result of the infection. Likewise, this understanding of God and the human also explains why Christian thought is able to denounce evil and injustice, campaign for a fair and a just world, value human life and human dignity, and call for more sustainable organs of human living alongside human nature that are mutually beneficial. It is out of that ethic of love and peace with justice that a fair and just distribution of wealth is demanded and the search for lasting and viable solutions to the human predicament is compelling.

Bishop Rowan Williams, former Archbishop of Canterbury, addressing the Synod of Bishops at the Vatican, Rome, in October 2012 explained that the human face that the man or woman of faith shows to the world is one not just marked by pain and suffering, however true that may be, but also one that displays the love and justice of God, the heart of Christ that cares, and the power of the Holy Spirit that blesses and glorifies. Therefore, in all that we do as church, we are reminded to be mindful at all times that it is not just a one-dimensional view of God that we show forth in full view of the world, but that in us Christ is coming to be known and God revealed to the world.

\section{Pastoral Care and Covid-19}

Finally, Covid-19 is ultimately never just about the person affected or dying in isolation at a point in time. It is about community and family, about dreams and aspirations. In reality it is also about lost hopes and tainted or broken futures. It is about understanding the social and psychological factors that bring about a broken society, or ill-health, or disease in individuals or communities, the sources and causes of pain and suffering, but ultimately in instilling human 
nature with hope and victory over life. The life of faith is also a celebration of life, of thanksgiving about what has been achieved, about the joys of human living and strengths to meet the challenges that fulness of life presents. The work of caring, of assurance and hope is an ongoing task for those who understand the dynamism of community that is formed and shaped by a selfless community. After all, Covid-19 systems must be put in place, families must continue to live wholesome lives, loved ones must be memorialised and humanised, and community that has been broken must be formed and re-formed. More importantly, broken families must be cared for, orphans must be cared for and nurtured. Above all, the values, cultures, the stories of life must be told, protected, and sustained for the sake of posterity. In a society that may have lost a whole generation of the elderly that transmission of common wisdom, culture, language, and values to the younger generation is a big loss that cannot be recovered. Religious communities formed as in churches, mosques, synagogues, temples, or in ceremonies in African traditional belief systems, or even individual believers, for example, must become important in sustaining the value of human life beyond death.

\section{$9 \quad$ Conclusion}

Insofar as Covid-19 is shrouded in mystery, in ignorance and deniability (as we have seen with leaders of some countries!), we do well to remember that to many people, many homes and many societies it has brought about nothing but despair, suffering, and pain. However, to the scientific world it will bring about new discoveries, some will win Nobel Prizes, and nations will bask in the glory of success where all was lost. Even with all the confidence we have in the Christ of Life, humanity has to live with the reality that we do not know, and instead search the mind of God for a revelation. Therefore, we can only say that we have reached a stage in the journey of life and are enjoined into a continuous exploration about God. "Who God is?" is a question that should preoccupy scholars and men and women of faith at times such as these. To put it another way: is it that we can talk about God before or God after the coronavirus? Is God steady, constant and unchangeable? Surely, God would have been surprised and moved by all the suffering, and God would wish to reach out in new ways to equip humanity for the challenges that we face in an uncertain world. It is thus excusable that many can come to the conviction that this God for them is hidden in the sores of the suffering and in the struggle to breathe. But it is also in the loving care of family and friends; in the pain they share with the afflicted, in the skill of the doctors and the care of the nurses. God is found 
in the resources made available to meet the challenge of Covid-19 in the spread of emergency field hospitals. But above all it is in the generosity of the neighbor to do what one can to give generously to aid the suffering that we come to know God.

Perhaps what looms largest in what we learn about God and about human nature is that we are not only inextricably intertwined with one another but also with God. That comes out of the ethics of responsibility by which human nature discerns and acts with responsibility, learns from past mistakes, and seeks only that which sustains human living. Human nature cannot any longer afford to embrace the cult of irresponsibility that marked previous generations.

Perhaps what looms largest in what we learn about God and about human nature is that we are not only inextricably intertwined with one another but also with God. For me that is best expressed in the Pauline idea of "the remnant" found in Romans 11:5-6: "So too at the present time there is a remnant, chosen by grace. But if it is by grace, it is no longer on the basis of works, otherwise grace would no longer be grace."

But Paul reminds us of the fragility of human life and the responsibility of those entrusted with the "treasure" of communicating the gospel to the world. "But we have this treasure in clay jars," writes Paul, "so that it may be made clear that this extraordinary power belongs to God and does not come from us" (2 Cor 4:7). Post-coronavirus the two hold together. Thereby we are reminded of the integrity of functions of God. There are no easy answers. Is it also not true that this God we are searching for is the one who gives us the intelligence and the resolve to so restructure our social and economic life as to ensure that inequality and injustice never again find others unable to enjoy the means of life so as to survive the onslaught of a Covid-19 virus. Global crises come in cycles and in a variety of scales. In a sense, history repeats itself. But more importantly, what are the lessons that we have learnt so that we proceed with wisdom into the future. It may be that in this instance humanity will learn to abide by the ethic of eco-justice, as Pope Francis teaches, and in the world that we may come to a realisation that ethical power is best when it is shared and the resources of the world enjoyed by all, and that opportunities of life are best enjoyed when all are shared equitably.

Feast of St. Peter and St. Paul, Apostles 2020. 